\title{
Bank financing for SMEs in Pakistan
}

\author{
Jawad Karamat*, Tong Shurong, Abdul Waheed, Nasir Mahmood \\ School of Management, Northwestern Polytechnical University, \\ Xi'an, 710072 Shannxi, P.R.China \\ Jawad Karamat, MBA, jawad@mail.nwpu.edu.cn
}

Key Words: Banks, Bank financing, SME, Supply side, Pakistan.

\begin{abstract}
In this paper we consider the supply side of credit for Small and Medium enterprises (SME). Several studies have been done regarding the demand side. In this paper a survey of banks in Pakistan was done. We categorized those banks into different segments. We want to see how the banks perceive the Small and medium enterprises. The banks in Pakistan have started showing interest in the SME sector. Many banks are now establishing SME sections in their branches. The banks now perceive the SME sector to be very profitable and there is intense competition in the market. The State Bank of Pakistan (SBP) is continually trying to encourage this sector. It has introduced many policies and financial institutions other than banks to help in providing finances. The SMEs are seen as an emerging market and are contributing to both employment and economy.

In this paper we want to check the willingness of these banks to provide credit. The lending and its requirements in Pakistan. We will determine how the collateral is valued.
\end{abstract}

\section{Introduction}

The SME have started to show their significance over the last few decades. They have caught the eyes of many policy makers and researchers. SMEs are now considered an important topic for economic development. They employ most of the people in the world. In Pakistan it is said to be 99\% of the employment[1]. Despite the advantages these SME are facing many troubles. Among them a major problem is financing. Many studies have shown that access to finance is a major issue for the SMEs. It is this lack of finance that causes poor performance and in some cases death of an SME. It is a known fact that if the SME are able to find credit, then cost of credit is more as compared to large firms[2]. In this study we will consider the supply side of the financing. The policy makers see the supply side of finance as a major issue. It is the root cause of inadequate finances. The method of banks and financial institutions operate is a little biased towards the SME. According to a research done by Hyytinen and Pajarinen [3], it shows that the main reason cited by banks as a reason for not financing is "opaqueness". By this term the banks mean that it is hard to determine if the SME poses the ability to pay back the loan or if they have the willingness to do so. In some countries the concept of "relationship lending" has started. It is a new concept introduced. It is said to be a solution to the "opaqueness" [4]. It is still in the early stages and is yet to be introduced in Pakistan.

\subsection{Financial institutions in Pakistan for SME}

At first it is important to mention the role of State bank of Pakistan (SBP). It is the central bank responsible for making and implementing the monitory policy of Pakistan. 
Since the establishment of State bank it has seen many ups and downs. At the time of inception it had very little reserve to work with. In the 1970's a nationalization movement was started. A large amount of banks were nationalized. This was a major blow for the SME sector. Many banking activity restrictions were imposed on the private sector. The focus of banks had shifted from SME sector to the financing of large-scale public sector manufacturing. After the nationalization movement the government quickly realized the problem faced by the SME. In order to rectify the mistake in 1972 the government established many small financial institutions that would help and support SME.

The SBP again in 2007 tried to make new regulations for the SMEs, so they can have better access to finances but failed to do so. The banks in Pakistan found it difficult to finance SMEs because their profitability was less as compared to large institutions. The other issues were, Banks' risk averse approach[5], Alternate liquidity deployment options[5], High transactional cost of serving SMEs[5], Lack of Financial Products' Innovation[5], Lack of legal framework, The banks inability to monitor the performance of SME to achieve high efficiency

The commercial banks of Pakistan are still not willing to finance the SMEs. It is due to this there is negative growth of $0.37 \%[6]$. This was recorded in the second quarter of 2015.

\subsection{Banks that finance SME in Pakistan}

The greatest financers of SME are the banks in the private sector. In the public sector it is only National Bank of Pakistan (NBP) that contributes about 8\% [7]. The other public sector banks have the third largest share.

Table 1: Contribution of Banks for SME

\begin{tabular}{|l|c|}
\hline \multicolumn{1}{|c|}{ Banks } & $\begin{array}{c}\text { \% Share in SME } \\
\text { Finance Portfolio }\end{array}$ \\
\hline Big-five banks & 43.4 \\
\hline Habib Bank Limited & 15.55 \\
\hline National Bank of Pakistan & 7.86 \\
\hline Allied Bank Limited & 7.46 \\
\hline Muslim Commercial Bank Limited & 6.72 \\
\hline United Bank Limited & 5.81 \\
\hline Private banks (excluding big 5) & 44.36 \\
\hline Public sector banks (excluding NBP) & 4.82 \\
\hline Foreign banks & 0.42 \\
\hline Islamic banks (excluding Al-Baraka Bank) & 4.82 \\
\hline Specialized banks & 2.19 \\
\hline Source: SBP, Econdic Survey 2008 & \\
\hline
\end{tabular}

Source: SBP, Economic survey 2008

\section{Research Methodology}

This study uses qualitative approach. Most of the data in this study was collected by Interview. This was done so that many details could be drawn out of the bank managers and employees. The interviews would give us an in-depth knowledge as to why banks don't want to finance SMEs. The qualitative method of research helps us in showing unanticipated findings and other descriptive data without assigning it numerical values. 
We have divided all the banks into 6 sectors (private, public, Islamic, specialized, Microfinance, and foreign). Minimum of one was considered from each segment. We interviewed with many different aspects. The first was about, what the banks think about the SME sector. Why the banks are so hesitant in lending to the SME. We will check the main concerns of the bank, whether it is the SMEs profitability, competition in the market, government regulations or lack of collateral. Secondly we asked if the banks had a specialized portion dealing with SME. If they had a specialized portion was it available in all the branches. Was the loan processed in that branch or was it sent to their area branch or head office.

Then finally we asked the banks the type of collateral they required. We asked them how the banks evaluated the collateral that was provided to them.

\section{Results and Discussion}

The results and discussion will be divided into three sections and discussed as mentioned,

\subsection{Banks perception of SME}

Upon doing this study and conducting several interviews we came to the conclusion, that the banks of all segments are interested in lending to the SME. The reason quoted by $70 \%$ of the banks is that this segment is quite profitable. The other $30 \%$ were not too eager to finance SME. The larger banks in private sector were more interested in financing. The banks have mentioned that there is a lot of competition in the market among SME.

When asked if competition was the reason of not giving loan, $40 \%$ said yes, $30 \%$ said no, $10 \%$ said cannot answer depends on SME situation and positon in market, and $20 \%$ said depends on the product and situation of market. The government regulation also affects the banks. The SBP is trying its level best to help the SME and encouraging the banks to lend. This can be seen by the establishment of SME bank in 2004. The SME bank works right under the SBP. Other than this bank many other financial institutions were established for the convenience of SME. Despite the constant efforts of the SBP the bank managers feel that the SBP should put in more effort. They believe the policies can be further improved and lending to SME can be made easier.

\subsection{Specialized Departments dealing with SME}

The microfinance and specialized banks exist for this reason, so it was need less to ask them this question. These banks however have fewer branches. If the SME owner wanted to access them they would have to come to the city where they are present. The loan would be processed within those branches. In the other four sectors all the banks have a separate portion for SME accept for a few banks. Not all the branches have a separate portion. The private and public banks have many branches. Some of them are in far off places. Due to this most of the dealing would be done in the area head branch.

\subsection{Type of Collateral, its valuation}

The method of valuing the collateral in banks is the same. There are some firms that are registered with the banks. The collateral does not need to be property; it can be a machine, government security or ownership deeds of any plant or building. Finally when the market value is determined, they reduce it by $15 \%$. This $15 \%$ varies from bank to bank, some use a higher rate some use a lesser rate but $15 \%$ is mostly used. The banks will then lend at $70 \%$ of the amount 
you require. The banks use the additional $15 \%$ to protect themselves from loss. The $70 \%$ is used because it is the requirement of State Bank of Pakistan. The entrepreneurs have to hire a lawyer and the valuation firm. The lawyer assists the entrepreneurs in the contract they sign. The valuation firm values the collateral. Both have to be paid by the customer. Finally there is insurance cost. The entrepreneurs have to insure their project or business in which they are working. They will not be given a loan unless the project is insured.

\section{Conclusions}

From the results it is quite clear that the banks are very much interested in the lending. They perceive the SME sector to be quite profitable. As time is passing more and more SME are being established and competition is increasing day by day. Almost $70 \%$ of the banks are willing to lend to the SME sector. The government is also trying to promote this sector. It comes up with a new policy every time to support SME. The SBP has introduced a bank along with many other small financial institutions to support SME. There is still however a problem with respect to accessibility. The large banks have introduced sections for SME in their branches but they are only in the city area. There is also the matter of how they evaluate their collateral. The asset taken into consideration is highly undervalued. This makes the entrepreneurs a little uncomfortable. Other than that the loan processing cost is too high. These are a few aspects that hinders the entrepreneurs from applying for loan.

\section{Abbreviations:}

SME: Small and Medium Enterprises

SBP: State Bank of Pakistan

NBP: National Bank of Pakistan

\section{References:}

[1]. Albert Berry, Khalid Aftab and Sarfraz Khan Qureshi, January 28-31, 1999, The Pakistan Development Review, Vol. 37, No. 4, Papers and Proceedings PART I

[2].IADB, 2004. Unlocking Credit: The Quest for Deep and Stable Lending. The Johns Hopkins University Press.

[3].Hyytinen, A., Pajarinen, M., 2008. Opacity of young businesses: Evidence from rating disagreements. Journal of Banking and Finance 32, 1234-1241.

[4] Allen N. Berger, Gregory F. Udell, 2006, A more complete conceptual framework

for SME finance, Journal of Banking \& Finance 30 (2006) 2945-2966

[5] Syed Samar Hasnain, January 2015, Role of Central Banks in Promoting SME Business Pakistan - case, Cairo SME conference Session 2.

[6] https://www.smefinanceforum.org/post/banks-in-pakistan-reluctant-to-support-smesfinancing

[7] State Bank of Pakistan, Economic Survey 2008. 